\title{
SOCIAL CAPITAL AND EDUCATIONAL ATTAINMENT AMONG RURAL COMMUNITY IN MALAYSIA
}

\author{
ROSLAN ABDUL HAKIM \\ Othman Yeop Abdullah Graduate School of Business \\ Universiti Utara Malaysia \\ RUSSAYANI ISMAIL \\ NOR AZAM ABDUL RAZAK \\ School of Economics, Finance and Banking \\ UUM College of Business
}

\begin{abstract}
The determinants of educational attainment among children have become one of the main research agenda among scholars, educationists and economists alike. In most studies, the focus is on the relationship between educational attainment and factors such as the quality of teachers, schools, educational technologies, curriculum design, the financial and human capital aspect of the families and the ability of children themselves. Recently, the focus has been expanded to explore the relationship between social capital and educational attainment. As an addition to the existing literature, this paper attempts to investigate the impact of social capital on educational attainment using a regression analysis based on a sample of 2500 households, gathered from a rural community in Terengganu, Malaysia. Six domains of social capital are used to arrive at the index of social capital. The argument advanced in this paper is that social capital, which could be viewed as the outcome of networking, cooperation and trust at the household level, is expected to have a positive impact on a child's educational attainment. Towards this end, we regress children's education attainment on social capital along with other relevant independent variables, i.e. family, children, school and neighbourhood characteristics. Interestingly, the result of our study reveals that the level of social capital that a family has, is found to be significant and has the expected positive sign. This finding implies that social capital at the household level appear to be a critical factor in determining a child's educational attainment. Thus, our finding lends support to the idea that social capital is a good predictor of children's is educational attainment.
\end{abstract}

Keywords: Social capital, educational attainment, rural community. 


\section{Introduction}

One of the main functions of education is to instil knowledge and skills in students, i.e. to enhance human capital, which is imperative for economic growth and development. Besides, education also performs another equally important function, which is nurturing socially accepted values and norms to the student. Thus, a well educated person is not only expected to have sound knowledge and skills, but is also expected to behave in accordance with the values and norms of the society, have a sense of social responsibility, as well as to be able to play a proper role in the society. The latter, i.e. to play a proper role in the society, requires interaction and engagement with the society at large. Thus the child's ability or skill to interact and engage with society, i.e. social capital, turns out to be another expected outcome of education. Education therefore, should produce higher social capital, which is found to be vital towards the overall development of the society (Putnam, 1995; 2000). Thus, it is not surprising to find that there are many empirical studies that have been carried out to examine the relationship between education and social capital. Putnam (1995, 2000), Brehm and Rahn (1997), Alesina and La Ferrara (2000a) for instance, found that there is a positive relationship between education and social capital. Despite huge literature discussing the importance of education in producing future social capital, the reverse, i.e. the importance of social capital as one of the factors that contributes to high achievement in education has equally gained much attention in recent literature, such as Colemann and Hoffer (1987), Bryk and Schneider (2002), and Steinberg (1996), to name a few. In fact Coleman (1988) has conceptualised the impact of families and their environment in particular to highlight the importance of social capital. Interestingly he categorises the family impact into three separate components, i.e. human capital, financial capital and social capital. Basically human capital refers to parents' education, financial capital refers to family's wealth or income and social capital refers to the density of interaction among parents, children and school.

Most of the early literature focusing on student's achievement has paid much attention to the first two types of capital with little attention given to social capital. However a continuously persistence gap in educational attainment among children has provided room for researchers to find other factors that could explain the gap. Thus social capital is believed to be one of the missing factors. The importance of social capital to explain the gap in a child's achievement 
basically lies on the premise that family interaction within the family itself (interelationship) and outside (social networking) will help to improve a child's achievement since larger social capital means better information and communication, greater social networking and group membership. Thus, we argue that the challenge for improving educational attainment among children therefore does not solely lie in technological or financial solutions to education, but also in the promotion of social capital at the household level.

Realising the importance of social capital in promoting a child's educational achievement, this paper attempts to investigate the relationship by using the primary data obtained from a rural community in Terengganu, Malaysia. Using the rural community in Terengganu, Malaysia as a case study, the paper attempts to investigate whether the results hold true for the case of Malaysia. We are mindful that the results should be interpreted with great caution and may not be generalised to represent Malaysia as a whole but nevertheless it is hopeful that the study will provide some understanding towards the impact of social capital on a child's educational achievement.

The rest of the paper is as follows. Section II provides a brief perspective on social capital, while section III discusses some of the existing empirical studies on social capital and education. Section IV describes the data and method. Section $\mathrm{V}$ presents the findings of the study followed by a conclusion in section VI.

\section{Perspectives on Social Capital}

In the last few decades, there is a growing interest among social scientists to investigate the role and contribution of social capital in achieving some specified desirable policy outcomes. Basically, the argument behind social capital is that, socialising is good. Socialisation will bring about the sense of connectedness between individuals and their families, friends, community and the rest of the society. This connectedness in turn generates what we term as social capital. Social capital thus could be regarded as another type of capital that can be added to the existing two categories of capital, i.e. financial and human capital. The difference is that this capital is regarded as "social" since this capital is only accessible in and through relationships with other human beings. As with other forms of capital, financial and human, social capital can be accumulated and depreciated. It can be accumulated through investment by having a broader and deeper interaction and participation in the society. The 
deeper the connectedness, i.e. the higher and greater the intensity of interaction (engagement, involvement or participation), the higher and larger the social capital is. However, unlike financial and human capital, social capital will depreciate when it is hardly used, but it will accumulate or increase when it is frequently used (Glaeser, Laibson \& Sacerdote, 2002; Adler \& Kwon, 2002).

As far as social capital is concerned, not only it could bring about intangible, psychological impact but will also have an effect on socioeconomic or tangible outcome, in the same way as financial and human capital. Investment in social capital is believed to successfully produce tangible (material or economic) gains to individuals and society. The gains are realised since social capital creates trust, which helps to reduce transaction cost (Fukuyama, 1995), and facilitate coordinated actions of individuals, and hence improve the efficiency and effectiveness of the society. In this regards, Putnam's view of social capital is worth mentioning. According to Putnam (1993):

“...functions of social organizations, such as trust, norms, and networks that can improve the efficiency of society by facilitating coordinated actions."

Indeed, many studies have shown that social capital has positive socioeconomic consequences. Those nations or communities endowed with a large and diverse stock of social capital are perceived to be in a stronger position to deal with poverty and vulnerability (Moser, 1996; Narayan, 1995), resolve disputes (Schafft, 1998; Varshney, 2000), take advantage of new opportunities (Isham, 1999), and achieve higher levels of growth and welfare (e.g. Knack \& Keefer, 1997; Rose, 2000). Besides, individuals, households or communities possessing more social capital are usually also healthier and happier (e.g. Rose, 1999; Arts \& Halman, 2004), have less corruption and more effective governments (Putnam, 1995), have enhanced economic achievement (Fukuyama, 1995), as well as attain better educational achievement (Coleman, 1988; Lopez, 1996; Teachman, Paasch, \& Carver, 1996; Etcheverry, Clifton, \& Roberts, 2001; Huang, 2008). Conversely, the lack of social capital can have the opposite outcome.

\section{Social Capital and Education}

There is vast literature discussing the importance of social capital and a child's academic success. According to Tsang (2009), it is Coleman (1988) who first relates the notion of social capital to education. 
Coleman is of the opinion that the level of 'connectedness' between the child and his or her family, friends, community and school is as equally an important determinant of the child's well being and educational development as human and financial capital.

In order to investigate the importance of social capital in determining educational success, various studies have been carried out by Coleman and his colleagues (Coleman \& Hoffer, 1987; Coleman, Hoffer, \& Kilgore, 1982a, 1982b, 1982c). In his study he found that religious schools, mainly the Catholic schools, reported much lower dropout rates and better learning outcomes compared to public schools. He relates his finding with the argument that religious schools tend to have higher social capital due to non-familial association that cross generation, which creates better functional communities and closeness of social structure. This, in turn, enables the children to gain the positive effects that accrue through high social capital. In another study, Coleman (1990) pointed out that social capital in family relations and in community social organizations are useful for the cognitive and social developments of children and youths. In other words, social capital is useful for creating human capital of students (Coleman, 1988). When discussing social capital, Coleman and Hoffer (1987) suggested that both the functional and structural components of social capital should be considered. A mere relationship will not bring about any productive interaction. Thus it is important to ensure the functionality of the relationship which can be enhanced through trust and good norms. Apart from the studies carried out by Coleman and his colleagues, other studies also have cited the importance of social capital in student achievement. Bryk and Schneider (2002) and Lee and Croniger (1994) for example, have reported that there is a connection between strong relationships and student achievement. The positive effect of social capital through parental involvement in schools has also been cited by Steinberg (1996).

Another study by Furstenberg and Hughes (1995) reported that parents' social investment in their children and the community (social capital), increase the chances of children graduating from high school and attending college. A study by Crosnoe (2004) revealed that emotionally distant relationships with parents were associated with declining academic achievement over 2 years of secondary schooling. Lopez (1996) cited that social capital in the form of conducive home and school environments are found to be very important factors in determining educational outcomes compared to socioeconomic status. His conclusion is based on his study among White and 
Latino youths. Etcheverry, Clifton, and Roberts (2001) examine the effects of social capital on the development of knowledge, skills, and attitudes among undergraduate university students. Their findings show that students' perceptions of social capital resources have direct and indirect effects on their educational achievement. They find that students' perceptions of support, specifically support derived from interactions with other students, are an important resource that relates positively to their academic self-concepts and their grades. Perhaps they should mention studies that show the importance of socioeconomics status on educational attainment.

Based on the studies that are mentioned here, it is worth noting that the importance of social capital in contributing towards high academic achievement cannot simply be ignored. The empirical results support the notion that higher accumulation of social capital is more likely to produce children with higher educational attainment. At the community level, better communication and interaction, trust, cooperation between the school authority, parents and the rest of the community, as well as tolerance to rules and regulations, could produce children with better educational attainment. Similarly, a household that has better information, and good interaction between parents and children, is expected to produce better and successful children. Therefore, social capital is regarded as a "catalyst" that could boost educational outcomes.

\section{Data and Method}

\section{The Data}

The data used in this study are primary data gathered through a survey carried out between May 15 and June 2, 2009 in Terengganu, Malaysia. The area under study consists of three districts, namely Dungun, Kemaman and Hulu Terengganu, which cover about three quarters of the total area of the state of Terengganu. The total population in these three districts is estimated to be about 416,600 , while the estimated number of households is 90,565 (Table 1).

The sample of the study consists of 2,500 households, which constitute about $3 \%$ of the estimated total number of households in the three districts. The sample was selected through a stratified random sampling method. In the 2,500 households, there are a total of 12,321 children. Our units of analysis in this study are children of 
the household heads who during the survey have reached the age of 24 and above. The reason is that, in Malaysia students normally graduate from universities at the age of 23 after completing 3-4 years of their university education. By limiting our sample to those who are 24 and above as well as due to missing values, the total number of observation in this study is reduced to 2085 .

\section{Table 1}

Sample of the Study by Districts (Number of Households)

\begin{tabular}{lccrc}
\hline District & $\begin{array}{c}\text { Total } \\
\text { Population }\end{array}$ & $\begin{array}{c}\text { Estimated } \\
\text { Number of } \\
\text { Households }\end{array}$ & Sample $^{*}$ & Percentage $^{*}$ \\
\hline Dungun & 164,000 & 35652 & 985 & 39.4 \\
Kemaman & 176,400 & 38348 & 1058 & 42.3 \\
Hulu Terengganu & 76,200 & 16565 & 457 & 18.3 \\
\hline Total & 416600 & 90565 & 2500 & 100.0 \\
\hline
\end{tabular}

Source. Malaysia. Department of Statistics. State/District Data Bank 2008.

*Authors' own estimation, assuming average household in Terengganu consists of 4.6 family members.

\section{Measures of Social Capital}

According to the literature, there is a disagreement on what constitutes social capital. Thus it is not surprising to find that there is also a disagreement on how social capital should be measured. Nonetheless, based on previous work and suggestions, Grootaert et al. (2004) summarized that social capital at the household level constitutes six domains. These are: a) groups and networks, b) trust and solidarity, c) collective action and cooperation, $\mathrm{d}$ ) information and communication, e) social cohesion and inclusion, and f) empowerment and political action.

In this study, we focus on the social capital aspect by giving attention to the importance of the role of the family within the community rather than within the family itself. We adopt Grootaert et al. (2004) to arrive at the measure of social capital. Table 2 shows 13 items covering the six domains of social capital that are used in the construction of the social capital index. All of the items representing each domain are in the form of "yes" or "no" answer. A value of 1 is designated to the "yes" answer, while the value of 0 is given to 
the "no" answer. In order to derive the social capital index for each individual household, the percentage of "yes" answers is calculated. Then this percentage is transformed into a scale of 1 to 10 by applying a linear transformation ${ }^{1}$, as below:

$$
\mathrm{Y}=\mathrm{h}(\mathrm{x})=1+(9 / 100)^{*} \mathrm{x}
$$

where $\mathrm{x}$ is the raw score (percentage of "yes" answers) and $\mathrm{Y}$ is the (social capital) index score. This social capital index is constructed for each household and is used in the estimation of the regression model.

Table 2

Social Capital Dimensions and Related Indicators

\begin{tabular}{|c|c|}
\hline Dimension & Items \\
\hline $\begin{array}{l}\text { Groups and } \\
\text { networks }\end{array}$ & $\begin{array}{l}\text { (i) Membership in formal or informal organisations } \\
\text { or associations. } \\
\text { (ii) Ability to get support from those other than family } \\
\text { members and relatives in case of hardship. }\end{array}$ \\
\hline Trust & $\begin{array}{l}\text { (i) Most people in the community can be trusted } \\
\text { (ii) Most people in the community often help each } \\
\text { other. }\end{array}$ \\
\hline $\begin{array}{l}\text { Collective a } \\
\text { and cooper }\end{array}$ & $\begin{array}{l}\text { (i) More than half of the community contribute time } \\
\text { or money towards common development goals. } \\
\text { (ii) High likelihood that people in the community } \\
\text { cooperate to solve common problems. }\end{array}$ \\
\hline $\begin{array}{l}\text { Information } \\
\text { communica }\end{array}$ & $\begin{array}{l}\text { (i) Frequently listen to radio. } \\
\text { (ii) Frequently read newspapers. } \\
\text { (iii) Frequently watch television. }\end{array}$ \\
\hline $\begin{array}{l}\text { Soci } \\
\text { inclu }\end{array}$ & $\begin{array}{l}\text { (i) Strong feeling of togetherness within the } \\
\text { community. } \\
\text { (ii) Feeling safe from crime and violence when alone } \\
\text { at home. }\end{array}$ \\
\hline $\begin{array}{l}\text { Empowern } \\
\text { political ac }\end{array}$ & $\begin{array}{l}\text { (i) Have control in making decisions that affect } \\
\text { everyday activities. } \\
\text { (ii) Vote in the last general election (2008). }\end{array}$ \\
\hline
\end{tabular}

\section{The Regression Model}

Basically there are three approaches in empirical studies on educational attainment (Wilson, 2001). First, is the human capital approach where education is viewed as an investment good and this investment brings about economic returns. Based on the 
corresponding expected returns, the individual then will choose the level of education that he or she desires. This approach assumes that the returns to human capital is important and will have an impact on the level of education that the individual chooses to undertake. However, this approach ignores other factors that may directly influence the process of education itself such as the quality of school and family, which has an impact on the education outcome of the individual. Second, is the education production function approach. Following this approach, education attainment is viewed as output, while the variables (factors) that contributed towards producing the output (educational attainment) are viewed as the inputs. Inputs in the process of education could be the teachers, parents, and schools, that play important roles in education. In contrast with the human capital approach, the education production function approach assumes that the environment (i.e. inputs) in which the student (children) receives education is of utmost important, but it however, appears to ignore the role of returns to education. Third, is the combination of the two approaches where the reduced-form equation is estimated without any attempt to understand the underlying mechanism through which the independent variables affect educational attainment. This approach simply examines the relationship that is present among education, earning (returns) and the education environment (such as school and parents, quality).

In this study, we follow the educational production function approach. This approach has been employed for instance by Pritchett and Filmer (1997), Hedges, Greenwald and Laine (1994), Glewwe, and Kremer (2006), Todd and Wolpin (2003), Hanushek (2003) and Fehrler, Michaelowa, and Wechtler (2009). Following this approach, this study regards educational attainment as output, while the educational environment, i.e. the education process that may have an impact on the output are viewed as the inputs. Here, we divide inputs into four categories: the household or family, school, neighbourhood and children characteristics. Thus, the educational production function can be generally stated as follows:

Child education attainment $=\mathrm{f}$ (Household or family characteristics, School characteristics, Neighbourhood characteristics, Children characteristics)

Our dependent variable of interest (educational attainment) is measured by the number of years of schooling for the children from each household who are at the age of 24 years and above during our survey. The independent variables are categorised into four main 
groups, i.e. family, school, neighbourhood and child characteristics. Following Coleman (1988), we classify the family factors into three main categories: financial capital, human capital and social capital. In our study financial capital refers to household income, family size and the ratio of education expenditure to the total household expenditure. Human capital refers to parent's education and we use the index of social capital based on six domains as explained in the text to measure social capital. We further add the marital status of the household's head since previous studies show that the marital status (i.e. either single parent or divorced mother) will have an impact on student's achievement.

Based on the availability of data at the district level, we managed to get the student per teacher ratio to represent school characteristics. The student per teacher ratio is calculated based on the registered number of students in each particular district and divided by the number of teachers in that district. Due to data limitation and time constraint, we were not able to obtain the ratio for each individual school, so our assumption was that, schools that reside in the same district will have the same ratio. For the neighbourhood characteristics we used the ratio of the number of registered students in each district to juvenile cases in each district to show the extent or degree of safety in the neighbourhood. Therefore the higher the ratio the safer the community is. Gender and birth order are used to measure child characteristics. Table 3 summarises the dependent and independent variables involved in the study.

Table 3

Definition of the Variables

\begin{tabular}{|c|c|}
\hline Variables & Definition \\
\hline \multicolumn{2}{|l|}{ Dependent variable } \\
\hline Education attainment & $\begin{array}{l}\text { Years of schooling of children aged above } \\
24 \text { years }\end{array}$ \\
\hline \multicolumn{2}{|l|}{ Independent variables } \\
\hline \multicolumn{2}{|l|}{ Household characteristics } \\
\hline Household income & Monthly household income (RM/month) \\
\hline Number of children & The number of children in the household \\
\hline $\begin{array}{l}\text { Ratio of education } \\
\text { expenditure to total } \\
\text { expenditure }\end{array}$ & $\begin{array}{l}\text { Monthly expenditure on education /total } \\
\text { monthly household expenditure (RM/ } \\
\text { month) }\end{array}$ \\
\hline
\end{tabular}

(continued) 


\begin{tabular}{|c|c|}
\hline Variables & Definition \\
\hline Social capital & $\begin{array}{l}\text { Index of household social capital (Index } \\
\text { value of } 1 \text { to } 10 \text { ) }\end{array}$ \\
\hline Father's education & Years of schooling of the father \\
\hline Mother's education & Years of schooling of the mother \\
\hline $\begin{array}{l}\text { Marital status of the head of } \\
\text { household }\end{array}$ & $\begin{array}{l}\text { Dummy variable }(0=\text { married; } 1=\text { single } \\
\text { parent/divorced })\end{array}$ \\
\hline \multicolumn{2}{|c|}{ School characteristics } \\
\hline Ratio of student to teacher & Number of student per teacher \\
\hline \multicolumn{2}{|l|}{ Neighbourhood characteristics } \\
\hline $\begin{array}{l}\text { Ratio of student to juvenile } \\
\text { cases }\end{array}$ & Number of students per juvenile case \\
\hline \multicolumn{2}{|l|}{ Children characteristics } \\
\hline Gender & Dummy variable $(1=$ male; $0=$ female $)$ \\
\hline Birth order & Birth sequence of the child in the family \\
\hline
\end{tabular}

Specifically our model can be represented by the following equation:

$$
E d u c_{i}=\beta_{1}+\beta_{2} \operatorname{Soc}_{i}+\mathrm{x}_{i}^{\prime} \gamma+u_{i}
$$

where $E d u c_{i}$ is child i's educational attainment measured by the number of years of schooling, $S c_{i}$ is the index of social capital and $\mathbf{x}$ is a vector of control variable which are summarised in Table 3. The model is estimated by the ordinary least squares (OLS) method. The summary statistics of the variables are shown in Table 4.

Table 4

Summary Statistics of the Variables

\begin{tabular}{lcrrc}
\hline Variables & Average & Minimum & Maximum & Std. Dev \\
\hline Education attainment & 11.29976 & 0 & 18 & 2.774096 \\
Household income & 2192.014 & 100 & 15750 & 1666.335 \\
Number of children & 6.846043 & 1 & 11 & 2.334501 \\
$\begin{array}{l}\text { Ratio of education expenditure to total } \\
\text { expenditure }\end{array}$ & 9.973357 & 0 & 68.18 & 11.26954 \\
Social capital & 7.367266 & 3.25 & 10 & 1.373475 \\
Father's education & 5.733813 & 0 & 16 & 3.090545 \\
Mother's education & 5.033094 & 0 & 14 & 3.284986 \\
Marital status of the head of household & 0.0019185 & 0 & 1 & 0.0437688 \\
Ratio of student to teacher & 7.556168 & 6.709743 & 7.712305 & 0.3014153 \\
\hline & & & & (continued)
\end{tabular}


IJMS 19 (1), 53-71 (2012)

\begin{tabular}{lcccc}
\hline Variables & Average & Minimum & Maximum & Std. Dev \\
\hline Ratio of student to juvenile cases & 628.8623 & 378.7234 & 1172.177 & 347.4673 \\
Gender & 0.5285372 & 0 & 1 & 0.4993047 \\
Birth Order & 2.541007 & 1 & 10 & 1.555089 \\
\hline
\end{tabular}

Note. Number of observations $=2085$.

\section{The Results}

The results of the study are shown in Table 5. In general, our study reveals that all variables which could be generally categorised as family characteristics and children characteristics are significant and have the expected signs in explaining the variation in educational attainment of children. However, our findings show that the variables which could be categorised as school and neighbourhood characteristics are not significant in explaining children's educational attainment. With regards to family characteristics, our finding shows that household income is significant and has a positive correlation with educational attainment of the child. We also discovered that the ratio of expenditure on education to the total household expenditure is also significant and positively correlated with educational attainment. These findings imply that the level of financial capital (resource) that the family has, as well as the percentage of financial resource that the family allocated to education relative to others, are important variables that effect the educational achievement of children. The number of children that the family has is also significant and has the expected negative sign. It implies that as the number of children that the family has increases, generally the level of educational attainment of their children declines. This is not surprising as many studies have also found similar results as ours (Downey 1995; Lillard \& Willis 1994; Parish \& Willis, 1993).

What is more interesting is that our variable of interest in this study, i.e. the level of social capital that the family has, is also found to be significant and has the expected positive sign. This finding implies that social relationships as well as networking of the family appear to be a critical factor in determining their child's educational attainment. Thus, our finding lends support to the idea that social capital is a good predictor of children's educational attainment. Besides, our finding also confirms previous studies that find the crucial role of social capital in educational attainment such as those by Coleman (1988), Etcheverry, Clifton and Roberts (2001), Astone, Nan and Sara McLanahan (1991), and Lopez (1996). 
IJMS 19 (1), 53-71 (2012)

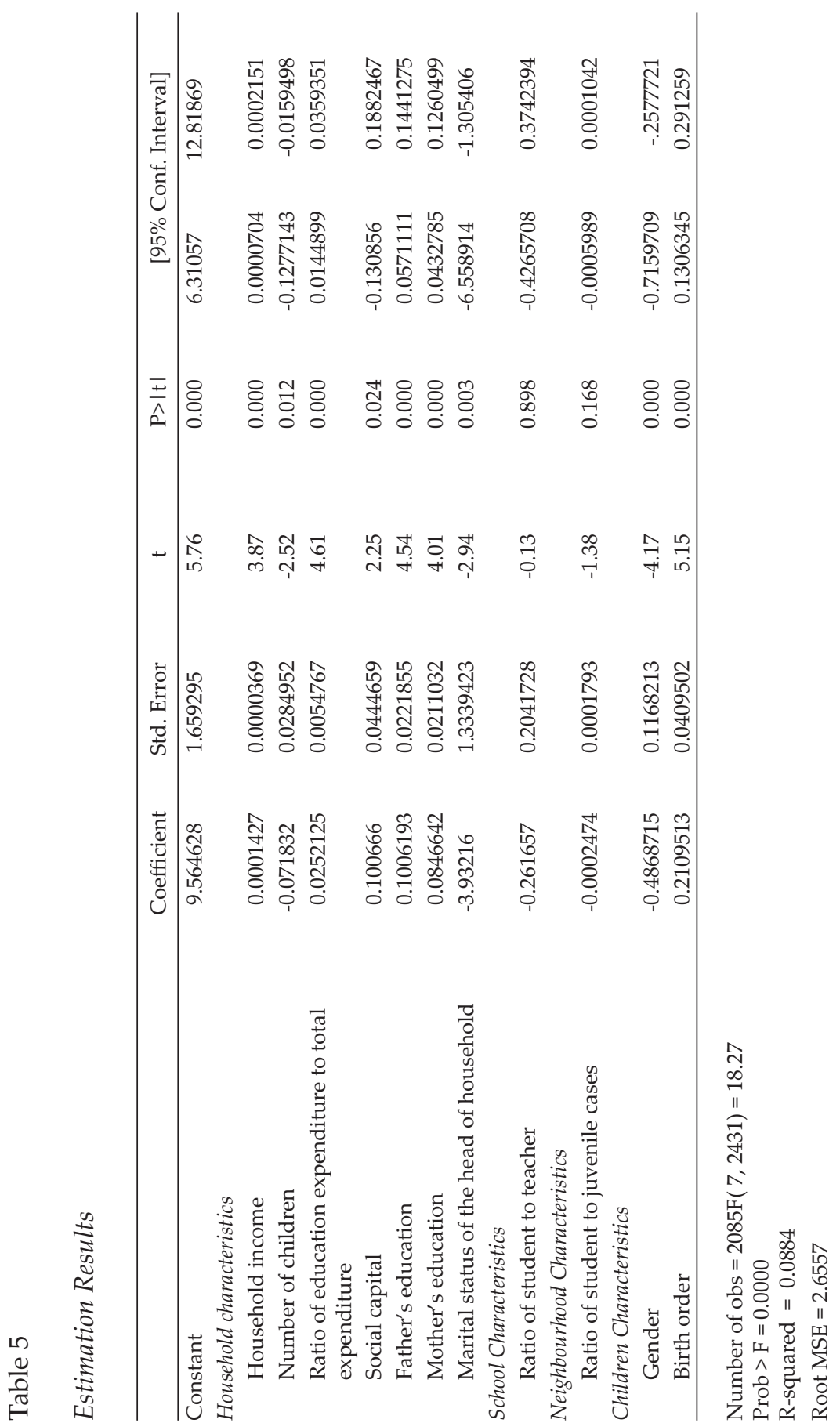


Furthermore, our study also uncovers that parents' education, which could be viewed as human capital at the family level, is also significant and positively correlated with children's educational attainment. Again, this is not surprising at all as the evidence of this positive correlation between parents' educational level and the child's educational attainment is also found in other studies such as that of by Boocock (1972). It is also interesting to discover that the parental family structure, whether the family is intact or broken as indicated by the marital status of the head of household, is also crucial in children's educational achievement. Our result shows that children from divorced parents (single parents) tend to have lower educational attainment than those with parents who are still intact. Our finding indicates that broken marriages (family) did have negative consequences on children's educational attainment. Studies by Astone and McLanahan (1991), Mare (1980) and McLanahan and Sandefur (1994) also found similar results. They found that children who grow up in divorced (single-parent) families are more likely to drop out of school compared to children who grow up in intact families.

Quite surprisingly, our study shows that school and neighbourhood characteristics are not significant in explaining the variation in children's educational attainment. We suppose that the explanations for these findings might be related to the limitation and quality of our data. As mentioned earlier, we were not able to obtain the ratios (student-teacher ratio and student-juvenile cases ratio) for each individual school. Thus, we used district data to represent data at the school level with the assumption that schools that are located in the same district will have the same ratio.

With regards to variables which could be grouped under children characteristics, interestingly, our study shows that the gender of the children did have a significant negative correlation with their educational attainment. The result indicates that female children tend to be more successful in education than male children. This finding might reflect gender differences in the attitude and motivation towards learning. Female students (children) in general are perceived to be relatively more diligent and more serious in their schooling than male students. Furthermore, we also found that the sequence of birth of the children in the family is significant and positively correlated with their educational attainment. This result signifies that, in a given family, younger children tend to excel more in education than older children. Probably this is due to the fact that younger children are 
blessed with natural-born teachers (i.e. their older siblings), and the number of these teachers increases with the number of offspring in the family.

\section{Conclusion}

The issue of the educational attainment of children is an important issue since raising knowledge and skills, which form one of the main goals of education, will contribute to the accumulation of human capital. Besides, education is also generally perceived to be the social leveller, i.e. an important factor to reduce inequality and social exclusion. Thus, the educational attainment of children is a serious issue that needs to be addressed since it is commonly found that there is a gap in the level of educational attainment among children not only between urban and rural areas, but also within the urban and rural areas itself. The existence of the gap in educational attainment implies that there might be a waste of human resources since the talents and potentials of the children are not developed to the utmost possible. The question then, is how to raise educational attainment and reduce the gap? Normally, to enhance as well as to reduce gaps in educational performance among children, an emphasis is given to the financial and human capital aspects. Thus, to reduce gaps in educational performance between rural and urban areas, for instance, policy makers tend to give more attention in enhancing school facilities and allocating quality teachers in the rural areas via financial and human capital investment. The contention of this study is that social capital at the family level as well as at the school and community levels are as important as financial and human capital. We argue that social capital at all of these levels - family, school and community - has long been disregarded in the effort to reduce the gaps in the educational performance of children. Addressing this question entails an investigation on the determinants of educational attainment. Identifying the determinants is important since it will guide policy-makers on figuring out what works and what does not. Towards this end, we examined the case of educational attainment among children in rural Terengganu, Malaysia. Specifically, we examined the relationship between social capital and educational attainment.

Our finding reveals that social capital, which is our variable of interest in this study, is found significant and is positively correlated with educational attainment. This finding lends support to our 
contention that social capital plays an important role in determining the educational attainment of children. This implies that raising the educational attainment of children requires more than investment in physical and technological development of education. At thehousehold (family) level, our study reveals that investment in social capital, such as by enhancing networking, cooperation and participation in local community activities, as well as accessibility to information and communication technologies (ICTs), would also help towards raising the educational attainment among children. Furthermore, reducing the gap between the urban and rural educational achievement level, as well as within the urban and rural itself, requires not only reducing the gap of schools in terms of physical, technology and human capital investment, but effort must also be given to reducing the gap in social capital between families and communities. Perhaps, this could be achieved by encouraging parents to cooperate and participate in local community programmes such as through the Parent-Teacher Association (PTA).

\section{End Note}

1. See Laporan Kajian Indeks Persepsi Integriti Nasional 2007 by the Institut Integriti Malaysia (2008). Retrieved from http:// www.wildlife.gov.my

\section{References}

Adler, P. S., \& Kwon, S. W. (Jan, 2002). Social capital: Prospects for a new concept. The Academy of Management Review, 27(1), 17-40.

Alesina, A., \& La Ferrara, E. (2000). Participation in heterogeneous communities. Quarterly Journal of Economics, 115, 847-904.

Arts W., Halman L. (2004). European values at the turn of the millennium. Brill: Leiden.

Astone, N., \& Sara, McLanahan. (1991). Family structure, parental practices and high school completion. American Sociological Review, 56, 309-320.

Bryk, A. S., \& Schneider, B. (2002), Trust in schools: A core resource for improvement. New York: Russell Sage Publications.

Brehm, J., \& Rahn,W. (1997). Individual-level evidence for the causes and consequences of social capital. American Journal of Political Science, 41, 999-1023. 
Coleman, J., \& Hoffer, T. B. (1987). Public and private schools: The impact of communities. New York: Basic Books.

Coleman, J. (1988). Social capital in the creation of human capital. American Journal of Sociology, 94, S94-S120.

Dasgupta, Partha \& Ismail Serageldin (Eds.). (1999). Social capital: A multifaceted perspective. Washington, DC: World Bank.

Department of Statistics (2008). State/District Data Bank 2008.

Dika, S. L., \& Singh, K. (2002). Applications of social capital in educational literature: A critical synthesis. Review of Educational Research, 72, 31-60.

Downey, D. B. (1995). When bigger is not better: Family size, parental resources, and children's educational performance. American Sociological Review, 60, 746-761.

Etcheverry, E., Clifton, R. A., \& Roberts, L. W. (2001). Social capital and educational attainment: A study of undergraduates in a faculty of education. The Alberta Journal of Educational Research, Vol. XLVII (No. 1, Spring), pp. 24-39.

Fehrler, S., Michaelowa, K., \& Wechtler, A. (2009). The effectiveness of inputs in primary education: Insights from recent student surveys for Sub-Saharan Africa. Journal of Development Studies, 45(9), 1545-1578.

Fukuyama, F. (1995) Trust: The social virtues and the creation of prosperity. New York: The Free Press.

Glaeser, E., Laibson, D., \& Sacerdote, B. (2002). An economic approach to social capital. The Economic Journal, 112 (November), F437-F458.

Glewwe, P., \& Kremer, M. (2006). Schools, teachers, and education outcomes in developing countries. In Handbook of the economics of education, Volume 2.

Hanushek, E. A. (1986). The economics of schooling: Production and efficiency in public schools. Journal of Economic Literature, 24(3), 1141-1177.

Hanushek, E. A. (2003). The failure of input-based schooling policies. The Economic Journal, 113(485), Features (Feb., 2003), F64-F98.

Hedges, L. V., Greenwald, R., \& Laine, R. (1994). Does money matter? A meta-analysis of studies of the effects of differential school inputs on student outcomes. Educational Researcher, 23(3), 5-14.

Institut Integriti Malaysia (2008). Laporan Kajian Indeks Persepsi Integriti Nasional 2007. Retrieved from http://www.wildlife.gov.my

Isham, J. (1999). A model of technology adoption with social capital. Mimeo: Middlebury College.

Knack, S., \& Keefer, P. (1997) Does social capital have an economic payoff? Quarterly Journal of Economics, 112, 1251-1288. 
Kwok-Kuen Tsang. (2009). School social capital and school effectiveness. Education Journal, 37(1-2), Summer-Winter 2009, 119-136.

Lillard, L. A., \& Robert, J. W. (1994). Intergenerational educational mobility: Effects of family and state in Malaysia. Journal of Human Resources, 29, 1126-1167.

Lopez, E. S. (1996). Social capital and the educational performance of Latino and Non-Latino youth. (No. 11). East Lansing: Michigan State University, Julian Samora Research Institute.

Moser, C. (1996) Confronting crisis: A comparative study of household responses to poverty and vulnerability in four poor urban communities. Washington, DC: World Bank.

Narayan, D., \& Pritchett, L. (1997) Cents and sociability: Household income and social capital in rural Tanzania. World Bank Research Working Paper No. 1796. Washington, D.C.: World Bank.

Parish, W. L., \& Willis, R. (1993). Daughters, education, and family budgets: Taiwan experiences. The Journal of Human Resources, 28, 863-98.

Paul, G., \& Michael, K. (2005). Schools, teachers, and education outcomes in developing countries. Retrieved from http://www.givewell.org

Pritchett, L., \& Filmer, D. (1997). What education production functions really show: A positive theory of education expenditures. Retrieved from http://unpan1.un.org

Putnam, R. (2000) Bowling alone: The collapse and revival of American community. New York: Simon and Schuster.

Putnam, R. (1995) Bowling alone: America"s declining social capital. Journal of Democracy, 6(1), 65-87.

Putnam, R. D., Leonardi, R., \& Nanetti, R. (1993) Making democracy work: Civic traditions in modern Italy. Princeton: Princeton University Press.

Rose, N. (2000) Community citizenship and the third way. American Behavioural Scientist, 43, 1395-1411.

Rose, R. (1999). Getting things done in an antimodern society: Social capital networks in Russia. In Dasgupta \& Serageldin, (Eds.), op. cit. pp. $147-71$.

Schiefelbein, E., \& Simmons, J. (1981). The determinants of school achievement: A review of the research for developing countries. Retrieved from http://idl-bnc.idrc.ca

Simmons, J., \& Alexander, L. (1978). The determinants of school achievement in developing countries: A review of the research. Economic Development and Cultural Change, 26(2).

Steinberg, L. (1996). Beyond the classroom: Why school reform has failed and what parents need to do. New York: Simon \& Schuster. 
Teachman, J., Kathleen, P., \& Karen, C. (1997). Social capital and the generation of human capital. Social Forces, 75, 1343-1359.

Todd, P. E., \& Wolpin, K. I. (Feb, 2003). On the specification and estimation of the production function for cognitive achievement. The Economic Journal, 113(485), Features F3-F33.

Varshney, A. (2000). Ethnic conflict and civic life: Hindus and Muslims in India, New Haven: Yale University Press.

Wilson, K. (2001). The determinants of educational attainment: Modeling and estimating the human capital model and education production functions. Southern Economic Journal, 67(3), 518-551.

Woolcock, M., \& Narayan, D. (2000). Social capital: Implications for development theory, research, and policy. The World Bank Research Observer, 15(2), 225-249. 